\title{
Global citizenship education through curriculum-as-relations
}

\author{
Eun-Ji Amy Kim ${ }^{1}$
}

Accepted: 25 February 2021 / Published online: 15 May 2021

(C) UNESCO IBE 2021

\begin{abstract}
The Covid-19 pandemic was a reminder of the importance of increasing connectivity amidst the accelerated rate of changes and disruptive events of our era. The need and the rationale for global citizenship education (GCED) were ever more emphasized by many educational organizations, including UNESCO. This article reviews the GCED discourses conceptualizing global competence as instrumental action and a binary view of global-local relations. In turn, the article proposes the idea of curriculum-as-relations for GCED. Curriculum-as-relations conceptualizes competence as situated praxis and focuses on providing authentic critical-translocal learning. Authentic critical-translocal learning through the strategy of comparison offers an alternative view of global-local relations as "articulated moments created by situated praxis". This new understanding of global-local relations may help different stakeholders to imagine GCED curricula beyond a Tylerian instrumentalist, ends-means orientation of curriculum.
\end{abstract}

Keywords Curriculum as relation · Global citizenship education · Translocal learning

The Covid-19 outbreak was a reminder of the increasing connectivity of diverse communities around the globe through digital technologies and networks. Fostering "a sense of belonging to a broader community and common humanity" has been a strategic area of UNESCO's education sector programs (UNESCO 2015, p. 14). With the United Nations (UN) Secretary-General's Global Education First Initiative (GEFI) in 2012, global citizenship education (GCED) has been continuously advocated by multilateral sectors, including UNESCO and other national and regional governments, and has remained a top priority during the Covid-19 outbreak. In response to Covid-19, UNESCO established the Global Education Coalition in April 2020. In their introductory video, Audrey Azoulay,

Eun-Ji Amy Kim

eun-ji.kim@griffith.edu.au

1 School of Education and Professional Studies, Griffith University, Room 2.31, Social Sciences Building (M10), Messines Ridge Road, Mt Gravatt, QLD 4101, Australia 
UNESCO's Director-General, referred to the current era as the "new age of learning... [where] the scale of challenges demands we need to act urgently and work together as one" (UNESCO 2020a, 0:39). Multiple calls were made for special project initiatives by the UN in response to Covid-19, focusing on three principles: innovation, partnership, and solidarity.

UNESCO's recent report entitled Humanistic Futures of Learning (2020b) emphasizes the importance of GCED "in a world of increasing complexity, uncertainty and precarity" (p. 4). The Covid-19 outbreak was a reminder that we can no longer predict the future of education as stable, assuming learning to be always continuous. As uncertainty became the norm, the structured "curriculum-as-plan" (Aoki 2004) had to be readapted to meet this new reality. Indeed, as William Pinar mentioned in the call for papers for this special issue, we need to focus on the issues arising from the immediate present and think of ways to "stay proactive" in this era of disruptive events. In thinking proactively with disruptive events and the discontinuity of learning as norms, I suggest a curriculum-as-relations as a curricular view for GCED that meets the current realities of this world of increasing complexity, uncertainty, and precarity. Here, curriculum-as-relations refers to curriculum that is driven by relationships and situated praxis (Aoki 1984). The overall aim of curriculum-as-relations therefore provides for authentic relationship-based learning opportunities involving actual encounters between locals, rather than following the popular slogan "think globally and act local". I will elaborate this further in the article.

Figure 1 shows the core elements of GCED through curriculum-as-relations. First, GCED through curriculum-as-relations acknowledges the need to transform the conceptualization of learning in the era of a learning economy. Beyond learning by doing and learning by listening, GCED through curriculum-as-relations focuses on providing opportunities for learning by interacting, a true relationship-based approach in which the focus is to develop "know-who" through words, skill sets, and knowledge that enable citizens to

Figure 1. Core elements of GCED through curriculum-asrelations

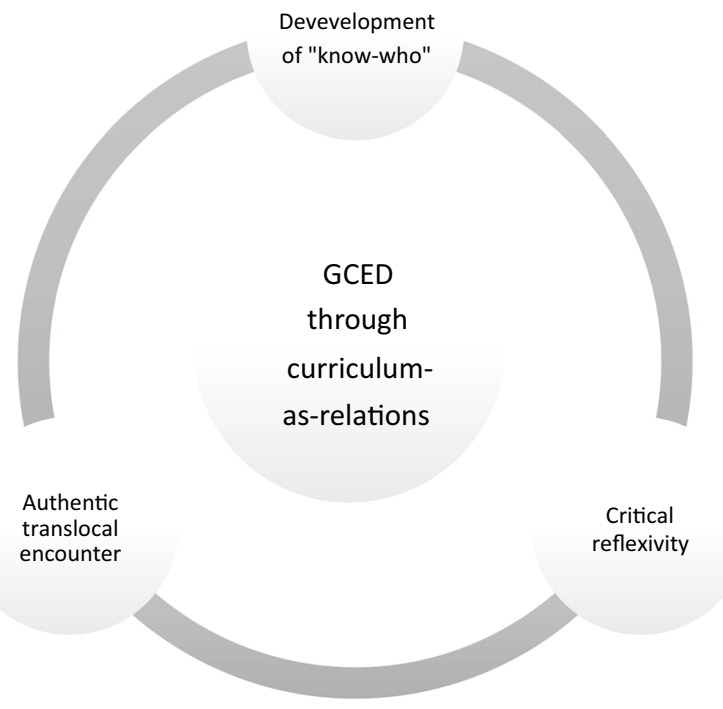


identify different stakeholders and actors and their expertise. Second, in the view of GCED through curriculum-as-relations, disruptive events (e.g., pandemic outbreaks) are considered the norm. Therefore, the core element of learning involves unlearning through critical reflexivity. Third, GCED through curriculum-as-relations focuses on providing authentic translocal encounters.

To further delve into the possibilities of GCED through curriculum-as-relations, I first explore global-local relations delineated in current GCED curricula.

\section{GCED in an instrumentalist view of curriculum}

Currently, GCED has no universal definition and conceptualization. Oxley and Morris (2013) identified eight categories of global citizenship from a literature review: political global citizenship, moral global citizenship, economic global citizenship, cultural global citizenship, social global citizenship, critical global citizenship, environmental global citizenship, and spiritual global citizenship. Each category draws from different theories and ways of framing what global citizenship entails. While many versions of GCED curricula exist, they are similar in that they seek to articulate and teach the moral, economic, and civic imperatives for a changing and connected global world (OECD 2018). For example, with respect to the moral imperative, it is argued that GCED can help prepare future citizens to live harmoniously in a globalized world consisting of "multicultural communities" (OECD 2018, p. 2). In that sense, GCED fosters values including "respect for diversity, solidarity and a shared sense of humanity" (UNESCO 2018, p. 2). With regard to the economic imperative, GCED prepares future citizens to thrive in a changing labor market (OCED 2018). In this light, "effective communication and appropriate behaviours" stemming from intercultural understanding, along with critical reflections on the set of technologies, become important aspects of global competence (OECD 2018, p. 5). Finally, concerning the civic imperative, GCED prepares future citizens to "participate in and contribute to the community at a range of levels from the local to global" (Giles 2019, p. 15). In this light, GCED promotes "understanding and acting on local issues in a global context, integrated with global drivers for responsibility such as the Universal Declaration of Human rights, the Sustainable Development Goals (SDGs)" (p. 15).

Current GCED curricula and frameworks argue for education focused on global connectedness and the fast-changing global world. GCED is to facilitate the development of multidimensional capacity/domains of global competence for individual learners. Here, I focus on two documents developed by international organizations: OECD's (2018) Preparing Our Youth for an Inclusive and Sustainable World: The OCED PISA Global Competence Framework and UNESCO's (2015) Global Citizenship Education: Topics and Learning Objectives.

PISA defines global competence as "a multidimensional capacity" (OECD 2018, p. 3), involving cognitive, socio-emotional, and behavioral knowledge and skills. There are four dimensions of OECD's global competence:

1. examine local, global, and intercultural issues

2. understand and appreciate the perspectives and worldview of others

3. engage in open, appropriate, and effective interactions

4. take action for collective well-being and sustainable development. (p. 26) 
In turn, as a global assessment tool, the PISA Cognitive Test for Global Understanding was created based on these four dimensions.

The concept of global competence as a multidimensional capacity is reflected in UNESCO's document as well. The topics and learning objectives for GCED were built based on "three domains of learning": cognitive (i.e., knowledge and thinking skills), socio-emotional (i.e., values, attitudes, and social skills), and behavioral (i.e., conduct, performance, practical application, and engagement) (UNESCO 2015, p. 19). Based on these three domains of learning, GCED learning outcomes, key learner attributes, topics, and specific learning objectives are listed in categories. Two popular views of GCED portrayed in these two documents are global competence as instrumental action and a binary view of globallocal relations.

First, the PISA Cognitive Test for Global Understanding and UNESCO's learning objectives by ages show us that global competence is viewed as instrumental action for learners to show and prove their knowledge, skills, and attributes related to GCED. Such a conceptualization is driven by a Tylerian-instrumental view of curriculum, what Ted Aoki refers to as "ends-means (technical) evaluation orientation". The ends-means evaluation orientation views knowledge as objective and a form of empirical data; it emphasizes "efficiency, effectiveness, predictability and certainty [of knowledge in curriculum]...in the service of control" (Aoki 1984, as cited in Pinar and Irwin 2005, p. 9). Ralph Tyler (1949) stated that curriculum should be based upon authority found in subject matter, social needs, and the needs of learners as individuals. Learning objectives are an important aspect for Tyler because they provide the educational goals that are sought and reflect the values of a society. As such, curriculum focuses on specifying goals and experiences for education in support of societal goals.

Following the Tylerian approach for GCED, stakeholders in multi-lateral organizations participate in imagining "the global" as "a utopic site of transgressive intermixture, hybridity and multiplicity" (Ang 1998, p. 14). Attempting to reach the vision of the global community, curriculum producers select specific societal goals, followed by learning topics and objectives. Teachers then select pedagogical approaches and a series of experiences for learners to develop global competence as conceptualized in GCED curricula. Such an instrumental view of GCED faces what Scott (2014) referred to as the external fallacy: knowledge and the future of the state are considered as "provisional, contingent and arbitrary... [but] curricular knowledge is identified exclusively in terms of specific social goals" (p. 6).

As pedagogical guidance, UNESCO's (2015) topics and learning objectives are to be contextualized at the "national level...with support from other partners and stakeholders" (p. 8). The document provides various examples of different countries' approaches to GCED linking with GCED objectives put forth by UNESCO. In a way, UNESCO seems to be promoting a glocalized approach of GCED. Here, I wonder how teachers and students conceptualize "the global": Is there a single, homogenized world of the global? In a way, the glocalized approach of GCED connects diverse locals under the name of GCED but considers global-local relations as an incommensurable binary whereby the global is always located outside the local.

Indeed, structured in the Tylerian-instrumentalist view of curriculum, GCED is viewed as something that can be delivered in a closed system, wherein global-local interactions are bounded by geographical borders in a causal manner. Curriculum offers pedagogy and activities that examine global-local issues as cause-and-effect transactions (e.g., How would local action impact global issues? Or global issues impact local action?). Through a linear, instrumentalist approach to competence-based curriculum, GCED operates with 
an abstract and decontextualized understanding of what the global community entails. In turn, teachers and students are confined in their own classrooms to offer actions that can be feasibly executed in their local surroundings. As such, popular slogans, including "think globally and act locally", are perpetuated within GCED curricula.

I see a global paradox in these GCED curricula and frameworks because "while it encourages all of us to think what unites us, it simultaneously fragments us by its incitation to focus our political practice on each of our immediate local surroundings" (Ang 1998, p. 26). Indeed, many GCED-related activities focus on action toward immediate local surroundings, while thinking of the impacts of their action globally or examining the issues critically in their classrooms. These activities do not necessarily require actual encounters with other communities. For these reasons, GCED has been criticized as being an empty term and a superficial gesture that is used by stakeholders for local agendas rather than fostering globally oriented citizens (Pais and Costa 2017).

These current GCED discourses assume the global economy is a knowledge-based economy. A knowledge-based economy is driven by neoliberalism, whereby individual competence is evaluated as a commodity for success. Exploring the influence of neoliberalism on curriculum is beyond my focus here. Here, I would like to focus on our current era conceived of as a learning economy. In 1994, economist Anne Carter already predicted that "the main function of most non-production workers is to introduce or cope with change" (Lundvall 2008, p. 5). Focused on the rate of accelerated changes in our current reality, Lundvall suggested that we are no longer in a knowledge-based economy. We are in the era of a learning economy, wherein "the success of individuals, firms, regions and countries reflect [emphasis added], more than anything else, their ability to learn [emphasis added]" (p. 2). To better distinguish a learning economy from a knowledge-based economy, I turn to my family story.

\section{Competence in a learning economy}

My grandmother was born in the 1920s and grew up in a small village in Korea. She did not attend formal school. She grew up helping her mother, farming, cooking, and doing chores. When she moved to a city, she worked as a production worker, offered her labor in a bakery, worked in a small garden, and sold products in a market. My grandmother's competence as a worker came from direct experience in the field.

In the 1960s, with the rise of new science-based industries, professional services, and other information-rich industries, many societies shifted toward a knowledge-based economy or knowledge economy (Powell and Snellman 2004). The shift toward a knowledgebased economy or knowledge economy required more skilled workers with specific expertise, and fewer general laborers. In turn, workers needed to show their competence in three different types of knowledge for the production process: know-what (e.g., knowledge about facts), know-why (e.g., scientific knowledge of principles), and know-how (e.g., skills) (Lundvall 2008).

My mother, who was born in the 1950s, attended formal schooling and went to a professional college to become a nurse. In college, she had to go through a curriculum specifically designed for her to develop the know-what, know-why, and know-how to work as a nurse. When she became a nurse, she continued to gain additional professional development courses and experience, while offering new suggestions for hospital services to administrators and offering training to new nurses. 
When living and working in a knowledge-based economy, knowledge is regarded as an asset for workers and as "a normal commodity" for industries, whereby such knowledge can be both as an "input (competence) and output (innovation)" (Lundvall 2008, p. 2). In the late 1990s to early 2000s, faced with a shortage of health professionals, some provinces in Canada launched the recruitment of internationally educated nurses. With the demonstrated knowledge base she had developed as a nurse, my mother immigrated to Canada through the recruiting program.

Now, in the era of a learning economy, we are witnessing "the growing cost of change" and "acceleration in the rate of change" in an economy driven by the rapid development and diffusion of digital technology and globalization (Lundvall 2008, p. 2). A learning economy requires workers with competence "that combines a complex knowledge base and a highly developed, rapidly changing specialisation" (p. 2). To thrive in the learning economy with its constantly fast rate of change, individuals need to have the ability to unlearn and adapt to the changes. For the unlearning process, critical reflexivity on previous experience becomes an important competence. To work with the constantly fast rate of change in the learning economy, individuals need to ask reflective questions about their lessons from previous tasks (e.g., What did I learn from previous experience? What do I need to unlearn for the next phase of change?), identify needs for the new tasks and contexts (e.g., What further knowledge do I need?), and locate experts for new knowledge and ways to communicate with experts from different disciplines (e.g., Whom should I reach to obtain the new technology and knowledge I need?). Unlearning through critical reflexivity leads to the development of know-who, which is considered most important in the learning economy.

Know-who involves information about who knows what and who knows how to do what. This information can only be accessed through "the formation of special social relationships with the expertise involved that makes it possible to access to and use their knowledge efficiently" (Lundvall 2008, p. 116). To identify actors and experts and to build relationships requires going beyond the conventional learning by doing or learning by using. It requires learning by interacting. Learning by interacting provides students with diverse experiences of relationship formation and communication through translocal and transdisciplinary encounters. The ends-means orientation of curriculum focusing on the competence of individual learners may not be sufficient for curriculum in a learning economy, which focuses on know-who through learning by interacting. I propose to conceptualize a curriculum-as-relations that focuses on embracing know-who through transdisciplinary learning as well as on learning-as-unlearning through critical reflexivity. In the view of curriculum-as-relations, the notion of competence is not focused on an individual learner's knowledge base (i.e., learning outcome). Curriculum-as-relations views competence as communal venturing (Aoki 1984), focusing on experiencing a series of translocal and transdisciplinary encounters together.

\section{Global-local relations as articulated moments created by situated praxis}

Ted Aoki put forth the notion of competence as communal venturing by looking at the Latin etymology of competence. The word competence comes from the Latin root competere: 'com meaning 'together,' and petere meaning 'to seek'. [...] to be competent means 'to seek together or to be able to venture forth together'" (Aoki 1984, as cited in Pinar and Irwin 2005, p. 6). In this light, Aoki continued to conceptualize competence as situated praxis, more precisely as "communicative action and reflection, [wherein] reality is constituted as a community of actors and speakers" (p. 8). Competence is viewed as a process 
of open dialogue between actors within a particular situation. The notion of togetherness is central in the view of competence as situational praxis. Grounded in the notion of togetherness, competence is then only obtained through learning by interacting. Curriculumas-relations with this view of competence as situated praxis re-envisions GCED beyond the ends-means technical orientation of curriculum. Curriculum-as-relations (re)imagines global-local relations as articulated moments beyond a geographical sense.

Ien Ang (1998) challenged the common practice in academia of associating "the local" when in defining a place. Such an association of the local with a place is observed in placebased education. Often when associating local with a place, place-based education asks learners to examine the specific historical, social, economic, and environmental contexts of that place. Following this, GCED conceptualizes local as the specific place, while global becomes decontextualized as place-less.

Instead of conceptualizing global-local relations solely based on a geographical notion of a place, both Ang (1998) and Massey (1994) suggested we focus on articulated moments. Massey suggested thinking of places "as articulated moments in networks of social relations and understandings" (p. 154). This understanding of places as articulated moments is aligned with Ted Aoki's notion of competence as situated praxis. It is through the communal venturing in a situation and through communicative action and reflection that "reality is constituted as a community of actors and speakers" (Aoki 1984, as cited in Pinar and Irwin 2004, p. 8). Drawing from Massey and Aoki, I suggest an understanding of a place as an articulated moment created by networks of social relations, with participants who dwell in a particular situation together. In this light, the place is social-situationaltemporal. There is no static notion of the place, because those articulated moments will continue to evolve based on the communal venturing process of actors. The global-local relations for curriculum-as-relations follows this definition of the place, focusing on interactions between actors. As such, global-local relations are "always-already crossroads, an intersection of global/local linkage" (Ang 1998, p. 25), a liminal space of learning in between articulated moments, driven by relationships between various actors from diverse places engaged in situated praxis (i.e., communicative action and reflection) together. Global-local relations are then framed as "articulated moments created by situated praxis".

I turn to Lim's (2019) explanation of global memory space to elaborate upon this idea. With the increasing connectivity through digital technologies and international mobility, people can share their experiences and views beyond their national/local borders. These personal thus necessarily partial views and experiences then contribute to global memory space, a social memory space that is "freed from national borders, [where] memories have become entangled, cohabited, reconciled, contested, and negotiated across borders" (p. 45). Lim listed a few examples of global memory spaces. He suggested that memories of the Holocaust and all other genocides and war crimes are linked and are cross-referenced in the global memory space of victimhood. Another type of global memory space has apologetic denial memories, which include deniers of the Holocaust, comfort women, the Nanjing massacres, and so forth. Through situated praxis, communicative action, and reflection together in the global sphere, the global memory space is created as a collection of partial yet diverse views, experiences, and stories. The discourses in global memory spaces become transnational, challenging the national state as the sole, legitimate holder of collective memories and instead creating "transnational civic virtue" and global solidarity (p. 51).

As illustrated by the three imperatives of GCED (i.e., moral, economic, and civic), fostering transnational civic virtue and global solidarity is a core aspect of GCED, particularly for its moral and civic imperatives. There are no meta-sovereigns to give rights as 
global citizens. Thus, global citizenship operates solely on the "responsibility to respect and promote human rights, cultural diversity, the environment and peace, and responsibility to behave in the way others expect and as we expect of others" (Giles 2019, p. 13). In this sense, the citizenship aspect of global citizenship is driven by global solidarity and transnational civic virtue rather than by tangible rights.

Curriculum-as-relations, with the notion of competence as situated praxis, offers tangible opportunities for learners to access and to contribute to global memory space. This would better serve to foster the three pillars of GCED: respect for diversity, solidarity, and a shared sense of humanity (UNESCO 2018, p. 2). In thinking about global-local relations as articulated moments, I am reminded of Donna Haraway's (1988) caution about the danger of relativism, as it is "a way of being nowhere while claiming to be everywhere equally" (p. 534). I am also mindful of not viewing global memory space and global-local relations as articulate moments and as a utopic place of intermixture and hybridity, overlooking the power dynamics necessarily involved. The Covid-19 outbreak allowed us to realize the increased connectivity of the world yet also provided a reminder of the economic and social disparities stemming from equity issues that continue to exist. While moving the learning space to a digital location, some communities/individuals suffered from an inability to access resources online. We witnessed more polarized stances from citizens on certain scientific and social issues (e.g., wearing masks and social distancing, and the extreme rise of xenophobia around the world). Most importantly, the Covid-19 outbreak allowed us to reflect on the influence of disruptive events on education.

Especially in a learning economy, changes in society will only accelerate. Such changes are not always gradual but rather sometimes sudden and filled with disruptive events. Curriculum needs to be developed with the understanding that sustainability of learning comes from accepting the unsustainability of learning. Rather than building curriculum to build a continuity of learning, perhaps what we now need is a radical conceptualization of the pathway of curriculum through what Andrea English (2013) suggested as "discontinuity of learning". In this light, GCED through curriculum-as-relations should consider disruptive events not as something to respond to but as a norm, which requires framing learning differently. In thinking about the ways in which curriculum-as-relations is actualized for GCED, I suggest the approach I refer to as authentic critical-translocal learning.

\section{Authentic critical-translocal learning for GCED}

First, my use of the term authentic involves emotional engagement through building relationships. In the context of learning in an indigenous community, Sandra Styres (2017) mentioned that the term "authentic refers to how traditional knowledges are transmitted in ways that are emotionally and relationally appropriate, significantly relevant, purposefully, and mindfully respectful, as well as ethically responsible" (p. 84). In this light, my use of authentic here refers to emotional engagement and the commitment to ethics and responsibility that comes with critical-translocal learning. Storytelling as a pedagogy allows for authentic moments. Here, I use Senehi's (2002) view on storytelling as "a sub-type of narration - the relating of narratives in person, orally (or by singing), to an audience of at least one" (p. 3). Storytelling allows individuals to understand human experience in relation to expanded context (e.g., space, land, and time). Storytelling as a methodology focuses on both collective identity (community) and individual identity (personal).

For instance, with Covid-19, rising numbers of racially motivated attacks and racist incidents toward Asians are being reported in many White-settler nations, including 
Australia, Canada, and the United States. Albeit located in different geographic regions, many global Asian diaspora communities in these countries are experiencing similar trends of discrimination, driven or accentuated by the Covid-19 pandemic. Asian diaspora communities used digital platforms to engage in storytelling. Via webinars and social media, various stories and views on Covid-19 pandemic-related racism incidents have been shared and cross-referenced in the global memory space of the victimhood of racially motivated incidents. This digital global memory space played a role as a catalyst for global solidarity and led to movements such as \#Iamnotavirus, \#hateisavirus, and \#takeouthate. Individuals used these hashtags as they shared their stories and experiences relating to Covid-19 pandemic-related stigma. These partial stories became a collective voice, further anchoring and informing the relationships being built through storytelling. These global digital movements did not occur via a top-down approach, where the initiative started or was suggested by an international/global multilateral organization; rather, they were the products of actual transnational and translocal encounters of people learning from each other through storytelling. Not all storytelling as a process results in positive emotional engagement or positive relationships. Sometimes destructive storytelling results in "intensify[ing] social cleavages and mistrust and perpetuate[ing] structural violence" (Senehi 2002, p. 45). Guiding "constructive storytelling as a means to bring issue to consciousness" is central for authentic critical-translocal learning (p. 45).

Second, my use of the term translocal resonates with Greiner and Sakdapolrak's (2013) notion of translocality as "emergence of multidirectional and overlapping networks that facilitate the circulation of people, resources, practices and ideas" (p. 375). In this light, translocality goes beyond the mobility of people through (im)migration, instead extending to the mobility of ideas and experiences of people. Indeed, the notion of beyond is important in conceptualizing translocality. Klein (2013) stated that "'inter' is conventionally taken to exist between existing approaches, while 'trans' moves beyond them" (p. 190). As such, trans requires creativity and moving beyond and thinking through what works best for articulated moments (i.e., the network of people gathered for a particular situation).

I conceptualize locals in the discursive sense rather than the geographic sense: locals are a network/community of people, ideas, and experiences stemming from the same or similar discursive practices. Translocality is then viewed as the networks of people and ideas, created by engaging in communication and reflection together. As seen in the Covid19 hashtag movements, the global memory space of \#Imnotavirus involved people from diverse places beyond national/local borders. My use of translocal therefore may be considered a local-to-local (community-to-community) connection, focusing on actual relationships being built through communicative action and reflection that functionally contribute to a global memory space.

Before moving to the exploration of critical, I delve into the notion of learning in relation to critical. Here, learning involves "a change in context of meaning and purpose for the individual and affect his/her existing knowledge" (Lundvull 2008, p. 5). The change is one's ontological shift through critical reflexivity. In this sense, learning is unlearning, "a realization of the incompleteness or wrongness of one's previous approach to things, in order to make room for a new way of seeing" (Sevilla 2016, p. 8). Therefore, learning for authentic critical-translocal learning is about learning to unlearn, where criticality is a key foundation.

Third, the criticality of the critical-translocal follows Foucault's (1988) notion of critique: 
A critique is not a matter of saying that things are not right as they are. It is a matter of pointing out on what kinds of assumptions, what kinds of familiar, unchallenged, unconsidered modes of thoughts, the practices that we accept rest. (p. 154)

Rather than critiquing others, criticality here respects the relationship that goes into forming ideas. Thus, building relationships allows for a critical process of uncovering the assumptions, unchallenged modes of thoughts, and practices at different levels, from the self to the community.

Global memory space does not always involve an idealized sense of connectedness of all stories and experiences. Rather, through the back-and-forth process of connecting and disconnecting, the people in the global memory realize diverse, situated, partial experiences and stories that are "stitched together imperfectly and therefore able to join with another, to see together without claiming to be another" (Haraway 1988, p. 586).

As such, for authentic critical-translocal learning, otherness and difference become the starting point, as an epistemological stimulus. Indeed, Fathi Triki (2020) suggested the "principle of otherness" gives a "human dimension" to education because it offers opportunities "to explain the uneasiness of cultures that are unable to dialogue" (p. 85). Experiences of this uneasiness, doubt, difficulty, or frustration-in Andrea English's (2013) words, "negativity of experiences"-is necessary because "learning necessarily involves confronting something that is as yet unfamiliar and new" (p. xxi). The term negative refers to the moment "when a person experiences a limit to his or her present ability or knowledge... [and becomes] aware that experience and learning are not merely positive and continuous, but also negative and discontinuous" (p. xxii). For authentic critical-translocal learning, the negativity of experiences from encountering otherness becomes a starting point, a source of theoretical insights for actors to see the limit of their current understandings and to understand the partiality of their experiences and stories (Takayama 2019).

The principle of absolute parity thus is fundamental for authentic critical-translocal learning. It promotes the idea that everyone brings partial views and experiences of a particular situation. As such, no actors bring the universal and complete understanding and experience of a situation. For instance, actors in the victimhood global memory space may share the commonalities of having lived experiences of violence, but the actual lived experiences these actors bring may be different. The Covid-19 racism victimhood global memory space contains various partial experiences of racially motivated incidents, ranging from physical violence (e.g., a man stabbed in front of a Korean store; vandalism in Chinatown in Montreal, Canada; two ethnically Chinese international students being abused on the street in Melbourne, Australia) to verbal abuse (e.g., being told to "go back to your country") to forms of microaggression (e.g., extreme drops in the number of customers in Asian restaurants in comparison with in non-Asian restaurants in the United States, driven by pandemic stigma). Some stories are contextualized within the particular historical and political context of a nation (e.g., White Australian policy in Australia, head-tax in Canada).

Lim (2019) warned of the potential competition over "who suffered the most" in the global memory space of victimhood driven by re-territorialisation and suggested that global memory space fluctuates between the processes of "de-territorialisation and reterritorialisation" (p. 46). As such, the strategy of comparison focuses on the articulated moments not only of connecting but also of disconnecting. When actors share and compare their partial experiences, they must go through what Ang (1998) referred to as "substantiation and specification" of metaphors and concepts (p. 27). This collective communicative action and reflection on metaphors and concepts together finding the commonalities 
and separateness of the experiences allows for fostering global solidarity and intercultural understanding beyond an arbitrary sense of global connectedness. In this light, the strategy of comparison is a relational and participatory approach through "finding 'us' while 'becoming me' where personal and collective co-constructed meaning making is crucial" (Agueda Marujo 2020, p. 49). While authentic critical-translocal learning may not offer a universal explanation of phenomena, it allows for the continual development of a global memory space for partial yet different experiences of a particular situation, such as the Covid-19 pandemic.

Drawing from all of the ideas illustrated here, authentic critical-translocal learning for GCED involves emotional engagement stemming from building relationships with other locals as well as critical reflexivity through translocal encounters, which leads to learning to unlearn process. Authentic critical-translocal learning, in this light, would not happen without actual encounters with other locals — that is, local in the discursive sense.

\section{Conclusions}

The Covid-19 pandemic was an opportunity to reflect on and reimagine the present and future of curriculum. Meanwhile, it reminded us to continuously strive to foster "respect for diversity, solidarity and a shared sense of humanity", the three pillars of GCED (UNESCO 2018, p. 2).

In this article, I illustrated that our era is no longer in a knowledge-based economy but rather in a learning economy where know-who and ability to unlearn through critical reflexivity become core assets. I suggested learning by interacting, which leads to a conceptualization of GCED focusing on competence as situated praxis rather than on instrumental action (Aoki 1984). Furthermore, I suggested the view of curriculum-as-relations.

As such, global-local relations are conceptualized beyond the existing geographic-spatial sense. The global-local relations I illustrated here include social-temporal-situational focusing on the network of people involved in communicating and reflecting together in a particular situation. Curriculum-as-relations thus focuses on providing an authentic critical-translocal learning experience through the strategy of comparison.

Curriculum-as-relations for GCED particularly helps to better contextualize GCED for indigenous and diaspora communities. For indigenous communities around the world, the notion of global citizenship may work differently, as many communities are working toward sovereignty as nations or being recognized as official political entities. The complicated nature of politics and identity work existing in many indigenous communities is often overlooked in the discussion about GCED. Curriculum-as-relations, focusing on local-tolocal connection in the global memory space (Lim 2019), allows GCED to occur beyond national identities and borders.

As mentioned before, the citizenship of global citizenship stems from a sense of responsibility driven by global solidarity. In the case of Covid-19 pandemic-related movements, such as \#Iamnotavirus, competence is storytelling as situated praxis, including communicative action and reflection. Such situated praxis in the global memory space facilitates the emotional engagement of listeners, potentially leading to the development of a sense of global solidarity.

The actual building of relationships and engaging in communal venturing could lead learners to build authentic global solidarity rather than an incomplete and utopic, superficial approach to this key aim. The development of curriculum-as-relations would then include the identification of different ways to critically examine and contribute to global 
memory space through storytelling. Therefore, the teacher's role is considered to be as a wayfarer (Takayama 2019) who facilitates conversation and leads translocal encounters.

For GCED to be meaningful yet stay proactive in the era of a learning economy, we need to focus on providing authentic critical-translocal learning opportunities. Only through actual encounters and relationships - rather than through meaningless actions for a decontextualized, place-less global community - can future citizens develop global citizenship and "a sense of belonging to a broader community and common humanity" (UNESCO 2015, p. 2).

Often educational researchers view the field's aim as "to be changed" and see learners as people to be transformed or as future citizens. Through curriculum-as-relations, GCED focuses on learners as active actors already contributing to global memory space. The students do not need to change. Each student may already be engaged in translocal encounters on their own with digital technologies. What we need is a curriculum that focuses on creating articulated moments for them to share their global-local stories.

\section{References}

Agueda Marujo, H. (2020). Participatory learning as a socializing process for global peace. In Humanistic futures of learning: Perspectives from UNESCO Chairs and UNITWIN networks (pp. 48-50). Paris: UNESCO. https://unesdoc.unesco.org/ark:/48223/pf0000372577.

Ang, I. (1998). Doing cultural studies at the crossroads: Local/global negotiations. European Journal of Cultural Studies, 1(1), 13-31.

Aoki, T. T. (1984). Competence as instrumental action and practical action. In E. C. Short (Ed.), Competence: Inquiries into its meaning mid acquisition in educational settings. Lanham, MD: University Press of America.

Aoki, T. (2004). Teaching as indwelling between two curriculum worlds (1986/1991). In W. Pinar \& R. L. Irwin (Eds.), Curriculum in a new key: The collected works of Ted Aoki (pp. 159-165). New York, NY: Peter Lang.

English, A. (2013). Discontinuity in learning: Dewey, Herbart, and education as transformation. Cambridge: Cambridge University Press.

Foucault, M. (1988). Practicing criticism. In L. D. Kritzman (Ed.), Politics, philosophy, culture: Interviews and other writings, 1977-1984 (pp. 110-124). London: Routledge.

Giles, L. (2019). Learning to live together and a life worth living. In APCEIU reconciliation, peace and global citizenship education: Pedagogy and practice (pp. 12-19). Incheon: UNESCO Asia-Pacific Centre of Education for International Understanding (APCEIU). https://www.gcedclearinghouse.org/ sites/default/files/resources/190516eng.pdf

Greiner, C., \& Sakdapolrak, P. (2013). Translocality: Concepts, applications and emerging research perspectives. Geography Compass, 7(5), 373-384.

Haraway, D. (1988). Situated knowledge: The sciences question in feminism and the privilege of partial perspective. Feminist Studies, 14(3), 575-599.

Klein, J. T. (2013). The transdisciplinary moment(um). Integral Review, 9(2), 189-199.

Lim, J. H. (2019). Global memory, global citizenship and reconciliation. In Reconciliation, peace and global citizenship education: Pedagogy and practice (pp. 44-51). Incheon: UNESCO Asia-Pacific Centre of Education for International Understanding (APCEIU). https://www.gcedclearinghouse.org/ sites/default/files/resources/190516eng.pdf

Lundvall, B. A. (2008). From the economics of knowledge to the learning economy. Globelics. https://www. globelics.org/.

Massey, D. (1994). Space, place and gender. Oxford: Polity Press.

OECD (2018). Preparing our youth for an inclusive and sustainable world: The OECD PISA global competence framework. Paris: OECD. https:/www.oecd.org/education/Global-competency-for-an-inclusiveworld.pdf

Oxley, L., \& Morris, P. (2013). Global citizenship: A typology for distinguishing its multiple conceptions. British Journal of Educational Studies, 61(3), 301-325.

Pais, A., \& Costa, M. (2017). An ideology critique of global citizenship education. Critical Studies in Education, 61, 1-16. 
Pinar, W. F., \& Irwin, R. I. (2005). Curriculum in a new key: The collected works of Ted T. Aoki. London: Routledge.

Powell, W. W., \& Snellman, K. (2004). The knowledge economy. Annual Review of Sociology, 30, 199-220.

Scott, D. (2014). Knowledge and the curriculum. Curriculum Journal, 25(1), 14-28.

Senehi, J. (2002). Constructive storytelling: A peace process. Peace and Conflict Studies, 9(2), 41-63.

Sevilla, A. (2016). Education and empty relationality: Thoughts on education and the Kyoto school of philosophy. Journal of Philosophy of Education, 30(4), 639-654.

Styres, S. D. (2017). Pathways for remembering and recognizing indigenous thought in education: Philosophies of Iethi'nihsténha Ohwentsia'kékha (land). Toronto: University of Toronto Press.

Takayama, K. (2019). An invitation to 'negative' comparative education. Comparative Education, 56, $79-95$.

Triki, F. (2020). Learning to become citizens of the world. In UNESCO humanistic futures of learning: Perspectives from UNESCO Chairs and UNITWIN Networks (pp. 82-86). Paris: UNESCO. https://unesd oc.unesco.org/ark:/48223/pf0000372577

Tyler, R. (1949). Basic principles of curriculum and instruction. Chicago, IL: University of Chicago Press.

UNESCO (2015). Global citizenship education: Topics and learning objectives. Paris: UNESCO. https://en. unesco.org/news/global-citizenship-education-topics-and-learning-objectives

UNESCO (2018). Global citizenship education: Taking it local. Paris: UNESCO. https://unesdoc.unesco. org/ark:/48223/pf0000265456

UNESCO (2020a). Global education coalition: Message from Audrey Azoulay, UNESCO director-general (Video). Paris: UNESCO. https://en.unesco.org/covid19/educationresponse/globalcoalition

UNESCO (2020b). Humanistic futures of learning: Perspectives from UNESCO Chairs and UNITWIN Networks. Paris: UNESCO. https://unesdoc.unesco.org/ark:/48223/pf0000372577/PDF/372577eng.pdf. multi

Young, M. (2005). Bridging knowledge back in: From social constructivism to social realism in the sociology of education. London: Routledge.

Publisher's Note Springer Nature remains neutral with regard to jurisdictional claims in published maps and institutional affiliations.

Eun-Ji Amy Kim is a lecturer at Griffith University (Australia), School of Education and Professional Studies. A former high school teacher,Amy is a curriculum consultant for Indigenous communities across Canada. She has collaborated with an Indigenous community (Kanienkehaka) in developing a land-based K-11 science curriculum. Her current research focuses on Indigenous-settler relations, allyship education and land-based teacher education. 